\title{
From Dusk to Dawn: Analysis of Anti-Money Laundering and Financing of Terrorism (AML/CFT) through Policymaking Stages in Kazakhstan and Kyrgyz Republic
}

\author{
Daniyar Sarbagishev $^{1 *)}$, Mergen Dyussenov ${ }^{2}$ \\ ${ }^{1}$ Department of Financial Policy, Eurasian Economic Commission, 2 Letnikovskaya St., bld \\ .1/2, Moscow, 115114, Russian Federation.
}

${ }^{2}$ Ministry of Culture and Sports of the Republic of Kazakhstan, House of Ministries, pr. Mugilik el 8, Nur-Sultan, 010000, Republic of Kazakhstan.

Received: 2020-09-05; Accepted: 2020-09-22; Published: 2020-10-27

\begin{abstract}
The article looks into Anti-Money Laundering and Combating the Financing of Terrorism (AML/CFT) policy issues through all stages of a policymaking process, across two Central Asian nations, Kazakhstan and Kyrgyz Republic. It does so through the prism of the role of key actors at each stage of policymaking. Among the key findings of this paper is that the implementation of anti-laundering policy in Kyrgyzstan has constantly been confronted with opposition from a range of key actors, specifically fractions within the parliament, as well as business communities and NGOs, while Kazakhstan faced policy implementation hurdles in a much less degree since both chambers of the national parliament did not express open resistance to the adoption of new amendments to the basic Law. Despite the higher resistance to AML/CFT policy implementation in the Kyrgyz parliament vis-à-vis its Kazakh counterpart, Kyrgyz Republic succeeded in passing the new Law due to a change in political power in 2017. Although both Kazakhstan and Kyrgyz Republic appear to move in the same policy direction overall while taking adequate measures to improve their AML/CFT policy systems in accordance with international standards, the specific stages of policymaking reveal interesting discrepancies, especially at the policy formulation and decision-making stages. This research appears to be the first and somewhat unique scholarly attempt to analyze a policy issue through a comprehensive policymaking cycle, i.e. all the way from agenda-setting to policy evaluation. More importantly, it looks into Central Asian context, the region that remains largely understudied.
\end{abstract}

Keywords: Policy Process Stages; Money Laundering; Central Asia; The Role of Actors in Policymaking

How to Cite: Sarbagishev, D., \& Dyussenov, M. (2020). From Dusk to Dawn: Analysis of Anti-Money Laundering and Financing of Terrorism (AML/CFT) through Policymaking Stages in Kazakhstan and Kyrgyz Republic. Journal of Contemporary Governance and Public Policy, 1(2), 92-107.

Permalink/DOI: https://doi.org/10.46507/jcgpp.v1i2.27 


\section{Introduction}

According to the 1996 IMF estimates, annually it is laundered from 800 billion to 2 trillion US dollars in the world, which is equivalent to 2-5 percent of global GDP (Vaknin, 2004). Legalization (laundering) of criminal proceeds is inherent in most forms of organized crime, and the process of laundering undermines and discredits financial institutions, exacerbates social problems, and also creates grounds for corruption.

Criminal proceeds can be used in a variety of ways, including covering the costs associated with the commission of crimes, investing in the criminal business, as well as financial support for terrorist organizations.

As for the financing of terrorism, today there are about 500 terrorist organizations in the world (the most famous are the Islamic State of Iraq and the Levant (ISIL), alQaida and the Taliban), which have carried out several thousand terrorist acts that killed tens of thousands of people in the last decade. The extent of damage from terrorist activities, the destructive power of terrorist acts is directly dependent on the amount of funds available to terrorist groups. The total budget of terrorist activities is up to $\$ 20$ billion annually (Supreme Council of Kyrgyz Republic, 2016).

The world community
recognizes that the legalization (laundering) of criminal proceeds, the financing of terrorist activities and the proliferation of weapons of mass destruction have become global threats to the economic security and integrity of the financial system. In this regard, states are required to take joint measures to combat these criminal acts, both at the national and international levels. All countries of the world, including Kazakhstan and
Kyrgyzstan, take measures to build a single legal space in the field of AntiMoney Laundering and Combating the Financing of Terrorism (hereinafter - AML/CFT).

Existing policy research tends to focus on a single stage of the policymaking process, e.g. agendasetting or policy implementation. Thus, in an attempt to fill this gap, this paper seeks to analyze AML/CFT policy through each of the policymaking stage as applied to country cases of Kazakhstan and Kyrgyzstan. It is largely focused on the assessment of current AML/CFT policy developments across the two Central Asian nations.

\section{Research Methods}

This research has been carried based on the content analysis methodology. While content analysis is widely applied across policy research applications (D. M. Hall \& Steiner, 2020; Yin, 2015), more specifically, it has been employed with regard to legal documents both related to domestic policymaking (Supreme Council of Kyrgyz Republic, 2016) and international legal policymaking processes and cases (The Eurasian Group, 2007, 2011)

Recently, the content analysis methodology has been applied to analyzing various legal policy documentation (e.g. Luzan 2011 who uses Russia's cultural policy as the major case; Salehijam 2018 who employs systematic content analysis as a valid tool to study a range of legal research cases including dispute resolution agreements). It were Hall \& Wright (2008), who pioneered the use of systematic content analysis as a research method that can be well applied to analyzing a wide range of legal research applications including judicial opinions. This method involves the collection of "a set of documents, such as judicial opinions 
on a particular subject... recording consistent features of each and drawing inferences about their use and meaning (M. A. Hall \& Wright, 2008). Furthermore, content analysis as applied to legal research "...brings the rigor of social science to our understanding of case law, creating a distinctively legal form of empiricism" (M. A. Hall \& Wright, 2008).

This research is grounded
onto the content analysis methodology as applied to AML/CFT policy through legal research lenses, across two Central Asian nations Kazakhstan and Kyrgyz Republic. In so doing, it attempts to analyze both domestic laws (Adilet Legal Information System of Kazakhstan, 2019; The Centralized Database of Legal Information, 2019) and international legislation sources (The Financial Action Task Force, 2019c, 2019b, 2019a).

\section{Key actors}

The AML/CFT system, as well as any other system, is an ordered organization of all its elements with the properties of integrity, divisibility, connectedness with each other, hierarchy (Zolotarev, 2014).

Conventionally, the AML/CFT system can be divided into 2 subsystems (levels) international, and national level.

The national level, in turn, can be divided into the state level and the primary core level.

The first (international) level of the AML/CFT system is an external environment composed of international organizations, associations, institutions, as well as international standards and rules that are sources of the formation of national AML/CFT systems.

The key actors of the first level include such international organizations as the FATF, FATF-style regional bodies (EAG - for Kyrgyzstan and Kazakhstan), the Egmont Group, Interpol, the International Monetary Fund, the World Bank, the UN and its structural divisions, the Basel Committee on Banking Supervision, Wolfsburg Group, G7, etc.

The second (national) level of the AML/CFT system, as previously noted, is divided into the state level, consisting of state bodies of a particular country, and the primary level, which includes financial institutions and non-financial categories of persons. Both state and primary levels are limited by national legislation.

include ${ }^{\text {Key second-level actors }}$ Commission on AML/CFT, the Financial Intelligence Unit or the FIU (the SFIS in Kyrgyzstan and the CFM in Kazakhstan), law enforcement agencies, prosecutors, judicial authorities, supervisors (regulators), other government agencies, selfregulatory organizations (this institute is developed neither in Kazakhstan nor Kyrgyzstan).

Finally, the primary level actors are financial institutions and designated non-financial businesses and professions (in Kyrgyzstan controlled entities, in Kazakhstan subjects of financial monitoring).

Together, through interaction, complementarity and hierarchy, these actors form the AML/CFT system (as in Figure 1). 


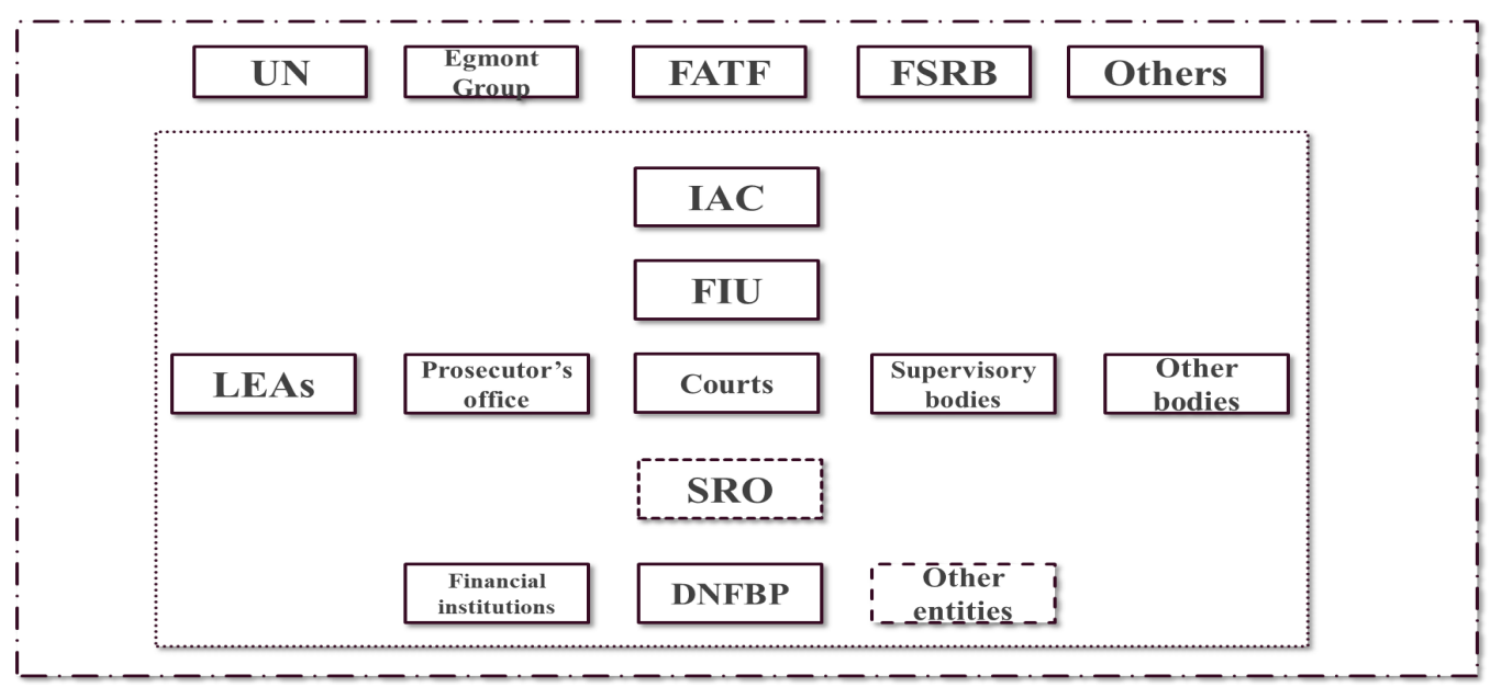

Figure 1. The Overview Diagram of the AML/CFT system

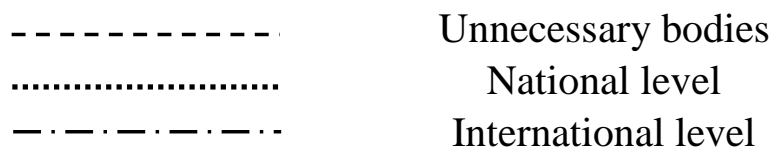

Source: The authors' own analysis

\section{Theory}

\section{An overview of the stages approach to policy analysis}

The analysis of policymaking through the stages approach, despite its shortcomings (Sabatier, 1991), was pioneered by Laswell (1956), which then became increasingly popular among scholars around the 1970s (Dye, 1972; Jenkins, 1978; Jones, 1970; May \& Wildavsky, 1978) that remains to be used by modern scholars (Howlett, Ramesh, \& Perl,
2003; Kulaç \& Özgür, 2017). According to the stages framework, the process of policymaking is basically viewed as a progressive cycle (Kulaç \& Özgür, 2017). While the earlier stages model incorporated seven stages of the policy process (Laswell, 1956), it eventually evolved into five major stages (as in pic. 2 below) - agenda-setting, policy formulation, decision-making, policy implementation, and policy evaluation (Howlett et al., 2003).

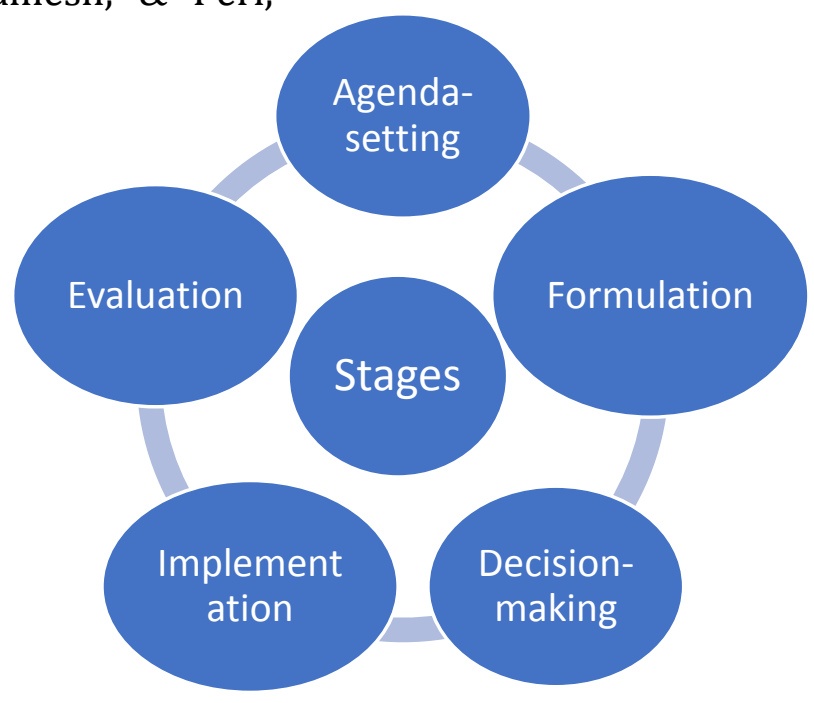

Figure 2. The classical sequence of stages of the policy process

Source: adapted from Howlett, Ramesh \& Perl (2009) 
A significant part of policy research employing the stages approach to analysis tends to explore a specific stage of the process, e.g. either agenda-setting (Dyussenov, 2019; Green-Pedersen \& Mortensen, 2010; Howlett, 1998), policy formulation (Howlett, Mukherjee, \& Woo, 2015; Howlett \& Rayner, 2013; Mardiyanta, 2013), decision-making (Knecht \& Weatherford, 2006; Teisman \& van Buuren, 2012), policy implementation (Grindle, 2017; Smith, 1973), or evaluation (McConnell, 2010; Vedung, 2017). A few existing studies either analyze a sequence from agenda-setting to implementation stages of the policymaking process (Gneiting, 2016; Pelletier et al., 2012), or analyze agenda setting and evaluation (Kim, Scheufele, \& Shanahan, 2002).

This paper, therefore, seeks to fill a gap in existing literature by analyzing anti-money laundering and combating the financing of terrorism (AML/CFT) issues across two Central Asian nations - Kazakhstan and Kyrgyz Republic - through each of the policymaking stage, all the way from agenda-setting to policy evaluation. In so doing, an attempt is made to look into the role of key actors involved at each stage of the policy process.

When analyzing the various stages of government policy on AML/CFT, several theories of policymaking can be applicable. Thus, according to the policy cycle theories (M. Howlett et al., 2003), the agendasetting stage is largely characterized by the Mobilization model (Cobb, Ross, \& Ross, 1976). Specifically, among the three modes of agendasetting - outside initiation, as applicable to liberal pluralist regimes; the mobilization model, more applicable to totalitarian regimes; and the inside initiation model - it is the mobilization model that seems best applicable to Central Asian context. This model recognizes key political decision-makers' attempts to expand policy issues from formal government (i.e. institutional) agenda to wider public (i.e. systemic) agenda (Cobb et al., 1976; Howlett et al., 2003). While the issue expansion involves debates within government units, the public remains a recipient. However, gaining public support is vital to ensure sound implementation of policy measures (ibid). This model is useful as the governments of Kyrgyzstan and Kazakhstan initiated to address AML/CFT policy.

In Kyrgyzstan, in the period from 2012 to 2018 during the promotion of a new draft law on AML/CFT, the government faced strong resistance from three forces: The Committee on Economic and Fiscal Policy of the Parliament, the NGO sector and the Union of Banks. This alliance may be similar to the "iron triangle" concept (Cater, 1964). Another useful theory here is the concept of issue networks (Heclo, 1978), since it can be argued that this alliance is rather temporary and had been formed only to counteract the promotion of anti-money laundering policy initiatives.

At the policy formulation stage, the NATO model (Hood, 1986), can be applied. Hood (1986) argued that governments can employ various tools when formulating policy, including nodality (use of information), authority (legal power), treasury (finance, budget), and organization (formal governmentaffiliated organizations).

Nodality-in the process of formulating the policy, the Kyrgyz and Kazakh authorities collected and utilized information on the size of the financial sector, the number and volumes of financial transactions, international standards and 
international experience of other countries.

Authority - regulatory draft legal acts, the FIU legal framework, minimum requirements for internal control rules, client and beneficiary owner questionnaires and other rules, guidelines and methodologies were developed.

Treasury - for the creation of an AML/CFT policy, appropriate national budget funds were allocated. In addition, at the stage of creating the AML/CFT systems, the authorities of Kyrgyzstan and Kazakhstan received substantial donor assistance from Russia, Ukraine and the United States.

Organization - one particular characteristic of AML/CFT policy is a relatively small number of public services, since this policy is aimed at preventing crimes, as well as facilitating investigations and trials. In this regard, the last element of the NATO model can only indirectly be linked to AML/CFT policy.

\section{Policymaking stages}

\section{Agenda-setting}

The origins of anti-laundering policy across the two countries are closely intertwined and have much in common. In October 2003, at the Plenary meeting of the FATF, Russia initiated the creation of an intergovernmental organization - the Eurasian Group on Combating Money Laundering and Financing of Terrorism (hereinafter - EAG), which later became a FATF-style regional body (The Financial Intelligence Unit, 2018).

The key actors at the agendasetting stage are the Governments of Kyrgyzstan and Kazakhstan, as well as international organizations such as the EAG, FATF and the UN.

The decision of the participating States to establish the EAG was taken at the Inaugural
Conference in Moscow in October 2004. The structure of this group, in addition to Russia, included Belarus, Kazakhstan, Kyrgyzstan, China and Tajikistan. 18 foreign countries and international organizations are currently observers in the EAG (The Financial Intelligence Unit, 2018).

The main goal of the Eurasian Group is to assist in the formation of national AML/CFT systems, to bring them in line with international standards, and to increase the effectiveness of these systems through international information exchange.

The Declaration on EAG Establishment as of October 06, 2004 states that the countries (including Kyrgyzstan and Kazakhstan) agreed to create the EAG "... taking into account the danger posed by actions for money laundering and financing of terrorism, reaffirming its commitment to maintaining economic security in the region and interest in protecting national financial systems from the use of criminal elements, recognizing the importance of broad international cooperation in countering the legalization of criminal proceeds and the financing of terrorism, expressing interest in setting up on the basis of the FATF recommendations, and taking into account the characteristics of the region an effective system of combating money laundering and financing of terrorism ... " (The Eurasian Group, 2011).

Thus, for the first time necessity to build anti-money laundering policy in Kyrgyzstan and Kazakhstan came 15 years ago, which was associated with the development of the economy and promote the use of banking services. In addition, building an AML/CFT system was also an international obligation of the two countries to the UN, since even then the most important UN conventions in the fight against drug 
trafficking, transnational crime, corruption, etc. were adopted.

In this regard, given the importance of fulfilling international obligations, and also in view of the danger of money laundering and terrorist financing, the governments of 2 countries were tasked to begin building AML/CFT state policy.

\section{Policy formulation}

At the policy formulation stage, a number of policy options or alternative actions to address a policy problem are usually explored (Howlett et al., 2003). The problem, as determined at the agenda-setting stage, was the lack of economic security of countries and, as a result, vulnerability to money laundering and terrorist financing.

It is important to note that Kyrgyzstan, as well as Kazakhstan, did not have any specific alternatives. The FATF (intergovernmental organization) requires the formation of AML/CFT systems in all countries worldwide; otherwise such countries are included in the sanction lists. For example, since 2011, the DPRK and Iran have been included in the FATF "black list" for refusing to cooperate (The Financial Action Task Force, 2019a).

Thus, in a semi voluntarycompulsory manner Kyrgyzstan and Kazakhstan adopted the 'rules of the game'. However, the countries had space for independent maneuver: for example, according to international standards, countries should have Financial Intelligence Units (hereinafter the FIU), which would have independence and autonomy. The concept of "independence and autonomy" did not mean that a country should create the body that would not report to any other organization. The main condition is that no one interferes in the activities of Financial Intelligence.
At this stage, both nations witness an analysis of the possibility to establish a Financial Intelligence Unit (FIU) based on international experience. There are 4 types of FIUs in the world: administrative, law enforcement, judicial and mixed (Forget \& Hočevar, 2004). Each type has its own advantages and disadvantages, but in many respects the type of FIU chosen depends on the characteristics of national legislation and the political regime. Considering that Russia played a special role in lobbying for the creation of an AML/CFT system in Kyrgyzstan and Kazakhstan (Rosfinmonitoring is an administrative type of the FIU), it is not surprising that the choice in these countries was to create an administrative-type FIU.

An administrative-type FIU, as a rule, has no investigative and operational-search functions (as opposed to a law-enforcement FIU). It is a kind of buffer between financial institutions and law enforcement agencies, which allows for a balance between maintaining banking secrecy and effective investigation of crimes (Forget \& Hočevar, 2004).

In addition, it was still necessary to identify the proper structure within which the FIU department would be located: under the President, under the Government, the Ministry of Finance or the National Bank. Other possible scenarios include placing it under General Prosecutor's Office, as in Uzbekistan or under police, as in Latvia.

Another key element in the formulation of AML/CFT policies is the adoption of a core regulatory framework. The development of basic legislation is one of the most difficult stages, since at that time there was no established practice and everything was created from scratch. As in the 
case of studying the issue of creating a FIU, Russia had a great influence on the development of AML/CFT laws in Kyrgyzstan and Kazakhstan.

Since the end of the last century, the AML/CFT policy has been formed in Russia. Russia has already managed to go into the FATF "black list", withdraw from it, and even become a full member of FATF. In this regard, Russia helped formulate an AML/CFT policy for Kyrgyzstan and Kazakhstan as their major strategic partner.

\section{Decision-making}

As noted earlier, the Russian policy experience helped Kyrgyz and Kazakh authorities to decide on how to develop AML/CFT policies. The administrative type of FIU was found useful in the two countries, and the AML/CFT legislation would be based on the Russian AML/CFT system. Russian experts assisted in the examination of draft regulations, thanks to which these draft laws were successfully submitted to the national parliaments for consideration.

Regarding the issue of jurisdiction of the FIU, Kyrgyz authorities decided to place such a body under the President, since at that time political power was concentrated in the hands of President. In addition, Kyrgyzstan focused on its Russian counterpart, where Rosfinmonitoring was under the jurisdiction of President. This approach was entirely based on the idea of Russia's President Vladimir Putin, who, as a former director of FSB, perfectly understood the great potential of the FIU in Russia. This is supported by the history of the formation of Rosfinmonitoring: the organization was under the President during Putin's presidency. When Vladimir Putin was Prime-Minister, Rosfinmonitoring was accountable to the government, and in 2012, when
Putin again became President, Rosfinmonitoring returned to the President (Rosfinmonitoring, 2019).

Despite the fact that in Kazakhstan the institute of the President was even more significant than in Kyrgyzstan, Akorda decided that it would be more correct to create a FIU within the Ministry of Finance. This approach is due to the peculiar structure of the Kazakh government, where ministries have a dominant role.

In both countries, it was decided to create approximately the same model of financial monitoring: financial institutions and DNFBP send information related to money laundering and terrorist financing to the FIU. The FIU, in turn, conducts a financial investigation and requests additional information from various sources. Then the FIU summarizes the information and sends the materials to the law enforcement agencies (in Kazakhstan, the materials are sent to the General Prosecutor's Office, which redirects them to the law enforcement agencies). Law enforcement agencies, on the basis of the materials, conduct an investigation, after which the materials go to the prosecutor's office, and then to the court. The court conducts the trial, and the bailiffs provide the court decision.

To conclude this part, while the Kyrgyz case witnesses the prevalent influence of a foreign government (i.e. Russian Federation authorities) lobbying both formulation and decision-making processes within parliamentary activities, the Kazakh case suggests that it is the national government itself (as represented by the Ministry of Finance) that appears to drive formulation and, consequently, decision-making parliamentary process. 


\section{Policy implementation}

In 2005, according to the decree of the President of the Kyrgyz Republic, the Financial Intelligence Service of the Kyrgyz Republic was established (now the State Financial Intelligence Service under the Government of the Kyrgyz Republic). It was empowered to receive, collect and analyze materials and information related to money laundering and terrorist financing. This body was included in the list of structures accountable to the President of the Kyrgyz Republic.

Kazakhstan, as noted earlier, decided to go the other way and create a Financial Intelligence Unit based on the Ministry of Finance. Thus, in 2008, the Committee on Financial Monitoring was established under the Ministry of Finance of the Republic of Kazakhstan (The Committee on Financial Monitoring of Kazakhstan, 2019). This body is accountable to the Minister of Finance of the Republic of Kazakhstan, but the Ministry is not entitled to interfere in the activities of the Committee, since this is a major condition of the FATF.

In Kyrgyzstan, this legislation was adopted in 2006, and in Kazakhstan in 2009. Currently, the laws of the two countries have undergone a significant change, since in 2012 international AML/CFT standards changed. Thus, in Kyrgyzstan, in September 2018, the new Law of the Kyrgyz Republic "On Combating the Financing of Terrorist Activities and Legalization (Laundering) of Criminal Proceeds" dated August 6, 2018 No. 87 came into force (The Centralized Database of Legal Information, 2019). In Kazakhstan, the Law "On Combating the Legalization (Laundering) of Criminal Proceeds and the Financing of Terrorism" dated August 28, 2009 No. 191-IV was updated several times by introducing amendments, with the more recent changes introduced on April 2, 2019 (Adilet Legal Information System of Kazakhstan, 2019).

The implementation of antilaundering policy in Kyrgyzstan has constantly been confronted with opposition from various forces, both within the walls of Parliament, and among business communities and NGOs. This was both in 2006 when the AML/CFT policy was born, and when developing a new Law, which could not be passed for more than six years. The catalyst for the development of AML/CFT policy was the change of political power in 2017 and support for the course taken at the highest level.

Kazakhstan faced problems of policy implementation in a much less degree since both chambers of Parliament did not express obvious resistance to the adoption of new amendments to the basic Law, unlike neighboring Kyrgyzstan. However, a number of international standards in terms of enhancing the customer due diligence measures against national public officials have not been implemented. Perhaps this is due to the conflict of interest among officials: no one wants their banking deals or transactions of their family members to be investigated under the strict control of the Committee on Financial Monitoring.

Next, the implementation of interaction mechanisms between the two levels of anti-laundering policy should be noted. For example, the FATF develops international standards on AML/CFT, which are binding for all member states (FATF 2019b). Kyrgyzstan and Kazakhstan at their level bring their respective national AML/CFT systems in line with these standards, since the FATF and its affiliated regional bodies have an effective mechanism for assessing 
countries' compliance with these standards. If a country fails to fulfill its international obligations, it risks falling into the sanction lists, with a negative effect on foreign investments, economy and reputation in the international policy community.

Another example of the interaction of national and international levels is cooperation through international organizations. Both Kyrgyzstan and Kazakhstan are members of the Egmont Group, an informal association of 159 FIU's member states worldwide (Egmont Group, 2019). Through a secure communication channel of the Egmont Group, Kyrgyzstan and Kazakhstan could effectively exchange operational details on money laundering and terrorist financing with most other countries, including with each other. Given the transnational nature of money laundering and terrorist financing, this type of interaction allowed the FIUs of the two countries to effectively assist in the investigation of these crimes.

Thus, the AML/CFT policy that is more in line with international standards has eventually emerged in Kyrgyzstan and Kazakhstan. The next and final stage of the policy cycle is the evaluation of this policy.

\section{Policy evaluation}

The last stage in the policy process is related to the evaluation of policy effectiveness in terms of its intentions (or policy goals) and results. In this regard, the AML/CFT policy should be evaluated by international organizations at the international level and by the public and the government at the domestic level.

At the international level, the AML/CFT system is evaluated by the FATF or its regional organizations.
Furthermore, both Kyrgyzstan and Kazakhstan are subject to evaluation by the Eurasian Group (EAG) as a FATF-affiliated regional body in the Eurasian region. There is a special methodology, rules for the procedure to carry out an evaluation, and other documents (FATF 2019c). The country is assessed for compliance with international standards on the basis of 40 FATF Recommendations. In addition, the effectiveness of implementing AML/CFT policies is evaluated by 11 Immediate Outcomes. In technical compliance, EAG experts check for the presence of laws, strategies, plans, rules, guidelines and other regulatory documents, while effectiveness assessment includes statistics, examples and other data.

In January-February 2007, the Kyrgyz Republic passed a mutual evaluation. The Mutual Evaluation Report was approved at the 6th EAG Plenary meeting.

Based on the results of the evaluation, the following ratings were set:
a. "Compliance" - 5 FATF Recommendations;
b. "Largely compliant" - 9 FATF Recommendations;
c. "Partially compliant" - 18 FATF Recommendations;
d. "Non-compliance" - 15 FATF Recommendations;
e. "Not applicable" - 2 FATF Recommendations (The Eurasian Group 2007).
In connection with these ratings, as well as in accordance with the EAG Mutual Evaluation Procedures, the Kyrgyz Republic fell under the procedure of enhanced monitoring. By the decision of the 9 th EAG Plenary meeting, due to the significant progress, the Kyrgyz Republic was removed from the enhanced monitoring regime. 
In October 2010, the mutual evaluation of the Republic of Kazakhstan through the EAG was held, during which a number of deficiencies in the AML / CFT system were identified. In June 2011, the 14th EAG Plenary Meeting approved the Kazakhstan Mutual Evaluation Report.

Based on the results of the evaluation, the following ratings were set:
a. "Compliance" - 1 FATF Recommendation;
b. "Largely compliant" - 12 FATF Recommendations;
c. "Partially compliant" - 18 FATF Recommendations;
d. "Non-compliance" - 16 FATF Recommendations;
e. "Not applicable" - 2 FATF Recommendations (The Eurasian Group 2011).
Ratings - "partially compliant" and "non-compliance" are set according to 4 key and 5 basic recommendations of the FATF. The final public statement of the 14th Plenary Meeting of the EAG noted a sufficient level of implementation by Kazakhstan of the FATF key requirements regarding the functioning of the financial intelligence unit. Certain institutional and regulatory mechanisms have been established through supervision and control, as well as within the law enforcement system. In this regard, a standard monitoring procedure has been established for the Republic of Kazakhstan.

In May 2018, at the 28th Plenary meeting of the EAG, Kyrgyzstan passed the second round of evaluation. Thus, according to the results of the evaluation, Kyrgyzstan received positive ratings on 27 ratings with 13 negative. In terms of effectiveness, the picture was more depressing: there were 3 low levels of effectiveness and 8 moderate ones out of 11 Immediate outcomes (The Financial Intelligence Unit, 2018).

In accordance with the schedule of mutual evaluation, Kazakhstan shall be evaluated in 2020, and at present, preparations for the next round of evaluation are underway.

The above-mentioned policy assessments at the international level are also an example of the interaction of two levels of actors. The expertsassessors of the FATF or EAG meet with government authorities, as well as with the private sector and NGOs to re-create a complete picture of the AML/CFT system. Only when interacting with all participants of the AML/CFT policy can the final conclusions be made on the national AML/CFT system.

With regard to evaluation by the public and the government, it should be noted that due to the secrecy, the public is poorly aware of the FIU activities. In Kyrgyzstan, citizens and members of Parliament often criticize the Government for the fact that it has an extra body that spends the national budget. In their opinion, it is advisable to liquidate the FIU of Kyrgyzstan or attach it to any department.

In Table 1 below the statistics of the State Financial Intelligence Service under the Government of the Kyrgyz Republic (hereinafter the SFIS) in terms of compensation for damage from economic crimes is shown.

Considering that the annual budget of the SFIS is about 25 million som, it is clear that the functioning of the body is profitable: the compensation for damage already exceeds the cost of maintaining the SFIS.

In Kazakhstan, the activities of FIU are even less known than in Kyrgyzstan. On the one hand, this is convenient, since there is no 
unreasonable criticism of the FIU, on the other hand it is difficult to promote AML/CFT policies without the high authority of the body.

Table 1. Submitted generalized materials for 2014-2018

\begin{tabular}{|c|c|c|c|c|c|}
\hline & 2014 & 2015 & 2016 & 2017 & 2018 \\
\hline $\begin{array}{l}\text { Submitted materials } \\
\text { to law enforcement }\end{array}$ & 32 & 38 & 46 & 37 & 61 \\
\hline $\begin{array}{l}\text { Damage caused (in } \\
\text { soms) }\end{array}$ & 8.86 billion & 7.37billion & 11.23billion & 5.9billion & 9.132billion \\
\hline $\begin{array}{l}\text { Damage repaired (in } \\
\text { soms) }\end{array}$ & 1.48billion & 1.7billion & 2.82billion & 3.9billion & 2.29billion \\
\hline $\begin{array}{l}\text { Damage reimbursed } \\
\text { based on the results } \\
\text { of the work of the } \\
\text { SFIS (in soms) }\end{array}$ & $\begin{array}{l}127.1 \\
\text { million }\end{array}$ & $\begin{array}{l}116.1 \\
\text { million }\end{array}$ & 253.7 million & $\begin{array}{l}249.3 \\
\text { million }\end{array}$ & $\begin{array}{l}290.7 \\
\text { million }\end{array}$ \\
\hline
\end{tabular}

\section{Discussion of key findings}

Notwithstanding common characteristics among the both Central Asian nations, e.g. common history, culture and traditions, the political and economic system of the region, this research points to a number of interesting differences as related to an analysis of AML/CFT policymaking across Kazakhstan and Kyrgyz Republic.

First, while both nations witness the prevalent power of the national governments at the agendasetting stage, the policy formulation and decision-making stages suggest certain discrepancies, i.e. while it is the Ministry of Finance that drives parliamentary processes in Kazakhstan, the Kyrgyz case reveals a different picture. It is a foreign government, i.e. Russian Federation, that exerted attempts to lobby both formulation and decision-making processes within Kyrgyz parliamentary activities to a larger degree vis-à-vis the Kazakh case. Furthermore, international organizations, e.g. FATF, shaped policy formulation in Kyrgyz Republic.

Second, the implementation of anti-laundering policy in Kyrgyz
Republic has constantly been confronted with opposition from a range of key actors, specifically fractions within the parliament, as well as business communities and NGOs, while Kazakhstan did not seem to face many policy implementation hurdles since both chambers of the national parliament did not express open resistance to the adoption of new amendments to the basic Law. It is worth noting that, despite strong opposition to the development of AML/CFT policy in the Kyrgyz case, it was eventually implemented as a result of the change of political power in 2017 and support for the course taken at the highest political level. Thus, the AML/CFT policy in line with international standards eventually emerged in Kyrgyzstan and Kazakhstan.

Finally, the AML/CFT policy evaluation is divided into two domains - the international and domestic, carried out by international organizations, and by the public and government agencies, accordingly. Based on the results of the evaluation, the following ratings were set with regard to Kazakhstan and Kyrgyz Republic. 
Table 2. FATF Evaluation: The case of Kazakhstan

\begin{tabular}{|l|l|}
\hline \multicolumn{2}{|c|}{ The case of Kazakhstan } \\
\hline “Compliance" & 1 FATF Recommendation \\
\hline "Largely compliant" & 12 FATF Recommendations \\
\hline "Partially compliant" & 18 FATF Recommendations \\
\hline "Non-compliance" & 16 FATF Recommendations \\
\hline "Not applicable" & 2 FATF Recommendations \\
\hline
\end{tabular}

Source: Adopted from the Eurasian Group (2011)

Table 3. FATF Evaluation: The case of Kyrgyz Republic

\begin{tabular}{|l|l|}
\hline \multicolumn{2}{|c|}{ The case of Kyrgyz Republic } \\
\hline “Compliance" & 5 FATF Recommendations \\
\hline "Largely compliant" & 9 FATF Recommendations \\
\hline "Partially compliant" & 18 FATF Recommendations \\
\hline "Non-compliance" & 15 FATF Recommendations \\
\hline "Not applicable" & 2 FATF Recommendations \\
\hline
\end{tabular}

Source: Adopted from the Eurasian Group (2007)

As outlined in tables 2 and 3 , it is interesting to observe that, although the number of "Partially compliant" and "Non-compliance" recommendations is similar across the both nations, they significantly differ in terms of "Compliance" and "Largely compliant" category recommendations. Specifically, while Kazakhstan is found to fully comply with only a single FATF recommendation (Table 2), Kyrgyz Republic complies with 5 (as in Table 3). On the other hand, Kazakhstan is "Largely compliant" with 12 FATF recommendations, while the Kyrgyz case suggests 9 recommendations. In overall, this evaluation analysis suggests that from an international organization's perspective, Kyrgyz Republic fares somewhat better vis-àvis Kazakhstan. From the domestic level evaluation, this remains more complicated. As mentioned earlier (Section 5.5), due to the secrecy of the AML/CFT policymaking process, the public across the both nations remain largely uninformed, while the government appears well interested in maintaining silence around the policy issue.

\section{Conclusion}

The development of AML/CFT policy in the Central Asian region is a timely, necessary and important phenomenon. In Kyrgyzstan and Kazakhstan, the AML/CFT policy was formed on a roughly equal footing, and therefore the key outcomes of the main agencies' activities, in general, significantly overlap if not coincide. The systems of the two countries are also similar, ranging from legislation in the field of AML/CFT, to the degree of involvement in the fight against new challenges and threats. For example, in the countries a campaign to research the mechanisms for protecting the financial system from money laundering and terrorist 
financing using crypto-currency and Blockchain technologies was launched at the same time. Despite the difference in the size of the financial market, countries are equally affected by alternative remittance systems, such as Havala, high cash flow, and also face the risk of the return of militants from Syria and territories controlled by ISIL. These facts can be used in predicting the development of AML/CFT policies of two countries in order to avoid the repetition of mistakes and to take preventive measures.

Although both Kazakhstan and Kyrgyz Republic appear to move in the same policy direction overall while taking adequate measures to improve their AML/CFT policy systems in accordance with international standards, the specific stages of policymaking reveal interesting discrepancies, especially at the policy formulation and decision-making stages.

This research appears to be the first and somewhat unique scholarly attempt to analyze a policy issue through a comprehensive policymaking cycle, i.e. all the way from agenda-setting to policy evaluation. More importantly, it looks into Central Asian context, the region that remains largely understudied. Further research should focus on replicating the complete stages-based policymaking analysis as applied to other developing nations. Other studies might employ this research approach with regard to other policy issues across the former Soviet nations, Eastern European nations, and beyond.

\section{Acknowledgments}

The authors are grateful to the Ministry of Culture and Sports of the Republic of Kazakhstan and Department of Financial Policy, Eurasian Economic Commission.

\section{References}

Adilet Legal Information System of Kazakhstan. Law of the Republic of Kazakhstan "On Combating the Legalization (Laundering) of Proceeds from Crime and Financing of Terrorism." , Adilet Legal Information System of Kazakhstan § (2019).

Cater, D. (1964). Power in Washington: A critical look at today's struggle in the nation's capital. New York: Random House.

Cobb, R., Ross, J.-K., \& Ross, M. H. (1976). Agenda building as a comparative political process. The American Political Science Review, 70(1), 126-138.

Dye, T. R. (1972). Understanding Public Policy. New Jersey: Prentice Hall.

Dyussenov, M. (2019). Who Sets the Agenda? Analyzing key actors and dynamics of economic diversification in Kazakhstan throughout 2011-2016. In Public Policy Research in the Global South (pp. 119-149). Cham: Springer.

Egmont Group. (2019). The official website. Retrieved from Egmont Group website: https://egmontgroup.org/

Forget, L., \& Hočevar, V. Š. (2004). Financial Intelligence Units: An overview. Washington: International Monetary Fund.

Gneiting, U. (2016). From global agenda-setting to domestic implementation: successes and challenges of the global health network on tobacco control. Health Policy and Planning, 31(suppl_1), i74-i86.

Green-Pedersen, C., \& Mortensen, P. B. (2010). Who sets the agenda and who responds to it in the Danish parliament? A new model of issue competition 
and agenda-setting. European Journal of Political Research, 49(2), 257-281.

Grindle, M. S. (2017). Politics and Policy Implementation in the Third World (Vol. 4880). Princeton: Princeton University Press.

Hall, D. M., \& Steiner, R. (2020). Policy content analysis: Qualitative method for analyzing subnational insect pollinator legislation. MethodsX, 7, 100787.

Hall, M. A., \& Wright, R. F. (2008). Systematic content analysis of judicial opinions. Calif. L. Rev., $96,63$.

Heclo, H. (1978). Issue Networks and Executive Establishment, the New American Political System. Washington, DC: American Enterprise Inc.

Hood, C. (1986). The Tools of Government. Chatham. NJ: Chatham House.

Howlett, M., Ramesh, M., \& Perl, A. (2003). Studying public policy: Policy cycles and policy subsystems. Oxford: Oxford University Press.

Howlett, M. (1998). Predictable and unpredictable policy windows: Institutional and exogenous correlates of Canadian federal agenda-setting. Canadian Journal of Political Science/Revue Canadienne de Science Politique, 31(3), 495524.

Howlett, M., Mukherjee, I., \& Woo, J. J. (2015). From tools to toolkits in policy design studies: the new design orientation towards policy formulation research. Policy \& Politics, 43(2), 291-311.

Howlett, M., \& Rayner, J. (2013). Patching vs packaging in policy formulation: Assessing policy portfolio design. Politics and Governance, 1(2), 170-182.

Jenkins, W. I. (1978). Policy-Analysis: $A$ political and organisational perspective. London: Martin Robertson.

Jones, C. (1970). An Introduction to the Study of Public Policy. Belmont: Wadsworth.

Kim, S.-H., Scheufele, D. A., \& Shanahan, J. (2002). Think about it this way: Attribute agenda-setting function of the press and the public's evaluation of a local issue. Journalism \& Mass Communication Quarterly, 79(1), 7-25.

Knecht, T., \& Weatherford, M. S. (2006). Public opinion and foreign policy: The stages of presidential decision making. International Studies Quarterly, 50(3), 705-727.

Kulaç, O., \& Özgür, H. (2017). An Overview of the Stages (Heuristics) Model as a Public Policy Analysis Framework. European Scientific Journal, 13(12), 144-157.

Laswell, H. D. (1956). The Decision Process. Bureau of Governmental Research. Maryland: University of Maryland, College Park.

Mardiyanta, A. (2013). Restore Public Trust Through Deliberative Public Policy Formulation. Bisnis \& Birokrasi Journal, 20(1).

May, J. V., \& Wildavsky, A. B. (1978). The Policy Cycle. California and London: Sage Publications.

McConnell, A. (2010). Policy success, policy failure and grey areas in-between. Journal of Public Policy, 345-362.

Pelletier, D. L., Frongillo, E. A., Gervais, S., Hoey, L., Menon, P., Ngo, T., ... Ahmed, T. (2012). Nutrition agenda setting, 
policy formulation and implementation: lessons from the Mainstreaming Nutrition Initiative. Health Policy and Planning, 27(1), 19-31.

Rosfinmonitoring. (2019). The official website. Retrieved from Rosfinmonitoring website: http://www.fedsfm.ru/

Sabatier, P. A. (1991). Toward better theories of the policy process. PS: Political Science and Politics, 24(2), 147-156.

Smith, T. B. (1973). The policy implementation process. Policy Sciences, 4(2), 197-209.

Supreme Council of Kyrgyz Republic. (2016). Background Justification to the draft Law.

Teisman, G. R., \& van Buuren, A. (2012). Models for research into decision-making processes: On phases, streams, rounds and tracks of decisionmaking. In Routledge handbook of public policy (pp. 317-337). Routledge.

The Centralized Database of Legal Information, M. of J. of K. R. The Law of the Kyrgyz Republic "On Combating the Financing of Terrorist Activities and the Legalization (Laundering) of Criminal Proceeds." , (2019).

The Eurasian Group. (2007). The Mutual Evaluation Report of Kyrgyzstan - 2007.

The Eurasian Group. (2011). The Mutual Evaluation Report of Kazakhstan - 2011.

The Financial Action Task Force. (2019a). FATF Methodology. Retrieved from The Financial Action Task Force website: https://www.fatf- gafi.org/publications/mutuale valuations/documents/fatfmethodology.html\%0A

The Financial Action Task Force. (2019b). FATF

Recommendations. Retrieved from The Financial Action Task Force website: https://www.fatfgafi.org/publications/fatfreco mmendations/documents/fatf -recommendations.html\%0A

The Financial Action Task Force. (2019c). Public statement. Retrieved from The Financial Action Task Force website: http://www.fatfgafi.org/publications/highrisk-and-other-monitoredjurisdictions/documents/publi c-statement-february2019.html

The Financial Intelligence Unit. (2018). The 2nd Mutual Evaluation Report of Kyrgyzstan- 2018. Retrieved from

https://fiu.gov.kg/uploads/5b b71d55027ce.pdf\%0A

Vaknin, S. (2004). Crime and Corruption. Salt Lake City: Project Gutenberg.

Vedung, E. (2017). Public Policy and Program Evaluation. London: Routledge.

Yin, R. K. (2015). Qualitative research from start to finish. New York: Guilford publications.

Zolotarev, E. V. (2014). Improving the system of combating money laundering and control mechanisms in credit institutions. Moscow State University.

(C) 2020 by Authors. Submitted for possible open access publication under the terms and conditions of the Creative Commons Attribution (CC-BY-SA) license (https://creativecommons.org/licenses/by-sa/3.0/). 